\title{
Growth and Physiological Responses of Rangpur Lime Seedlings Irrigated by a Prototype Subirrigation Tray
}

\author{
Carlos Vinicius Garcia Barreto ${ }^{1}$ \\ Instituto Nacional da Propriedade Industrial (INPI), 1 São Bento Street, Rio \\ de Janeiro, RJ, Brazil 20081-240
}

\author{
Rhuanito Soranz Ferrarezi ${ }^{1,2}$ \\ Department of Horticulture, University of Georgia, 1111 Miller Plant Science \\ Building, Athens, GA 30605
}

Flávio Bussmeyer Arruda

Biophysics Center, Agronomic Institute (IAC), 1481 Barão de Itapura Avenue Campinas, SP, Brazil 13020-920

\section{Roberto Testezlaf \\ School of Agricultural Engineering (FEAGRI), University of Campinas (UNICAMP), 501 Cândido Rondon Street, Campinas, SP, Brazil 13083-875}

Additional index words. capillary action, citrus rootstock, irrigation management, equipment development, water-saving technology

\begin{abstract}
Citrus rootstock production in Brazil commonly uses manual overhead irrigation systems to water plants. Manual irrigation systems present low efficiency, apply more water than needed, and result in release of nutrients and pesticides into the soil with a potential to contaminate groundwater. Closed irrigation systems that avoid the disposal of nutrient solutions like subirrigation can be used to increase production efficiency and reduce the environmental contamination. Our objective was to evaluate the effect of subirrigation applied by a prototype tray on plant growth and morphological and physiological responses of Rangpur lime (Citrus limonia Osbeck 'Limeira') seedlings subjected to different water levels in conic containers filled with pine bark substrate. We tested three treatments: T1) subirrigation with water reaching two-thirds of the container height $(8 \mathrm{~cm}) ;$ T2) subirrigation with water reaching one-third of the container height (4 cm); and T3) control with manual overhead irrigation. Subirrigation resulted in higher plant growth of Rangpur lime seedlings. At 90 days after sowing (DAS), we observed significant effects of $\mathrm{T1}$ over the other treatments on plant growth, as indicated by higher total dry mass $(P=0.0057)$, shoot/root ratio $(P=0.0089)$, shoot height $(P=0.0004)$, leaf area $(P=0.0005)$, and root length $(P=0.0333)$. The number of bifurcations was $400 \%$ higher in T3 than at the subirrigated treatments, which can lead to an increase in the labor costs for pruning. Seedlings grown under T1 presented leaf water potential $13 \%$ higher compared with $\mathrm{T} 3$ at predawn, which was the time of highest stomatal efficiency, presenting the lowest water loss, maximum stomatal closure, and higher transpiration at lower stomatal resistance. T2 plants displayed intermediate water status with a water potential $5 \%$ higher than T3. T3 plants showed a higher transpiration rate under maximum stomatal closure, reducing leaf water potential. The subirrigated treatment with water level of two-thirds of container height $(8 \mathrm{~cm})$ induced higher plant growth and shortened the crop cycle, anticipating the transplanting to the next phase (grafting) with the possibility of reducing production costs in the nursery.
\end{abstract}

Citrus industry is a prominent agribusiness in Brazil, generating thousands of direct and indirect jobs and a substantial income to all in the production chain. Citrus represents almost $50 \%$ of the country's fruit production (Brazilian Ministry of Planning, Budget and Management, 2012). Brazil is the world's largest orange producer with a cultivated area of 580,770 ha and a production of $15,384,048 \mathrm{t}$ in 2011 . In addition, Brazil is the largest exporter of frozen concentrated orange juice with a revenue of U.S. \$3.2 billion in 2012 (Brazilian Ministry of Development, Industry and Foreign Trade, 2012).

The success of the Brazilian citrus industry can be attributed to the use of high-quality seedlings, critical for maximum yield and health of orchards. The State of São Paulo banned the commerce and transportation of citrus rootstocks and citrus plants produced in field nurseries (Gonçalves et al., 2011), establishing a seedlings production system based on certified nurseries using screen houses that follows strict sanitary regulations. The mandatory use of antiaphid screens for protection against pests and disease vectors allows the production of healthy seedlings, permits traceability, and guarantees genetic quality, reducing disease spread in the field and increasing both tree longevity and productivity (Carvalho et al., 2005).
Manual overhead irrigation is used in $92 \%$ of the nurseries (Almeida, 2003; Salvador, 2010). This irrigation system involves overestimated irrigation volumes and high frequency to guarantee adequate substrate moisture (Ferrarezi et al., 2014). Mismanaged irrigation can increase plant losses and lead to uneven growth as a result of poor uniformity in substrate water content (Augusto et al., 2007; Landis et al., 2006). Manual irrigation systems also promote excessive water loss resulting from runoff and salt accumulation with potential to contaminate surface and groundwater (Soares, 2003).

As an alternative, subirrigation applies water to the bottom of pots using the substrate capillary action to wet the roots. The system has zero runoff (Uva et al., 2001), provides higher substrate soil moisture (Geneve et al., 2004), improves root water distribution, and induces greater root development (Augusto et al., 2007). One of many advantages of subirrigation is the maintenance of uniform substrate moisture. Excessive or deficient substrate water content levels negatively influence plant growth (Fachini et al., 2004; García-Sánchez et al., 2007). Subirrigation also has the potential to improve vegetative growth of citrus rootstocks (Teixeira et al., 2009) and shorten the crop cycle with minimal water wastage (Landis, 2005; Verdial et al., 1998). Moreover, this system eliminates the disposal of water with nutrients and pesticides into the environment because it is a closed system that recycles nutrient solution (Million et al., 1999).

Although subirrigation has a number of advantages over manual methods, improper use can result in increased salt concentration in the substrate surface (Richards and Reed, 2004) and changes in the root/shoot ratio of citrus rootstock seedlings in cases of prolonged saturation (Hartmond et al., 1987). This can result in lower specific root area and inhibition of seedlings canopy development, delaying the plant development (Ranney et al., 1991).

Roots under water saturation or drought stress for prolonged periods promote alterations in leaf gas exchange, resulting in morphological changes and hormonal imbalance in plants (Sojka, 1992). Irrigation management of nursery crops must address plant water requirements, which vary throughout different growth stages (Fachini et al., 2004). These changes occur as a result of a microclimate generated in a controlled environment (Machado et al., 2005; Pimentel et al., 2007) and the nutritional management used by the growers (Bañuls and Primo-Millo, 1995). These factors influence the plant physiology and, therefore, their growth, specifically shoot height and stem diameter, which are useful characteristics for transplanting citrus rootstock seedlings for grafting.

The School of Agricultural Engineering (FEAGRI) from the University of Campinas (UNICAMP), in Campinas, São Paulo, Brazil, has been performing studies since 2006 that aim to develop subirrigation equipment that can be used for citrus seedling growers to improve the efficiency of rootstock production 
in conic containers during sowing and to reduce the environmental impact. We developed a prototype tray, the "capillary irrigation equipment," to apply subirrigation on citrus rootstock seedlings production. This tray consisted of a closed reservoir in the bottom connected to polyvinyl chloride (PVC) pipes where the containers were inserted. The equipment was tested regarding to its application on Rangpur lime seedling production.

Our objective was to evaluate the effect of subirrigation applied by a prototype tray on growth, morphological, and physiological responses of Rangpur lime (Citrus limonia Osbeck 'Limeira') seedlings subjected to different water levels in conic containers filled with pine bark substrate.

\section{Material and Methods}

Location. The study was performed from Nov. 2009 to Jan. 2010 in Campinas, São Paulo, Brazil (lat. $22^{\circ} 48^{\prime} 57^{\prime \prime} \mathrm{S}$, long. $47^{\circ} 03^{\prime} 33^{\prime \prime} \mathrm{W}$, and elevation of $626 \mathrm{~m}$ ). Experimental plots were assembled in a Venlo-type greenhouse with $18.2 \times 6.4 \times 3 \mathrm{~m}$ (length $\times$ width $\times$ ceiling) and covered by $150-\mu \mathrm{m}$-thick agricultural polyethylene film with a frontal and side $0.87 \times$ $0.30-\mathrm{mm}$ antiaphid screen. The environmental conditions were not controlled, and the temperature ranged from 19 to $35^{\circ} \mathrm{C}$ and the relative humidity from $24 \%$ to $84 \%$.

Plant material. We used 30 -d old (30 DAS) Rangpur lime 'Limeira' seedlings grown in $12 \times 2.8-\mathrm{cm}$ (height $\times$ diameter) conic containers obtained from a certified commercial nursery (Citrograf Mudas, Conchal, Brazil). The average leaf area at the baseline was $18.95 \mathrm{~cm}^{2}$, and the total dry mass was $0.304 \mathrm{~g} /$ plant with the leaves representing $43 \%$ of the total mass. Containers were filled with fine-grained pine bark substrate (Terra do Paraíso, Holambra, Brazil) because of its favorable characteristics for capillary action (Barreto et al., 2012). The study was conducted until 90 DAS (23 Jan. 2010), when the last treatment reached an average shoot height of $18 \mathrm{~cm}$, as suggested by Boaventura et al. (2004) for transplanting seedlings in 5-L bags for grafting.

Subirrigation equipment. We developed a subirrigation prototype tray composed by two parts: a lower reservoir, made of acrylic

Received for publication 3 Sept. 2014. Accepted for publication 4 Nov. 2014.

This research was supported by the National Council of Technological and Scientific Development (CNPq), Brazil (grant no. 479.394/2006-7).

We thank Dr. Peter Otieno Alem, Ivo Zution Gonçalves, and the anonymous reviewers for their critical review of the manuscript and their suggestions. We also thank Capes Foundation (Ministry of Education, Brazil) for a scholarship to the second author as postdoctoral researcher at the University of Georgia (Proc. BEX 2620/13-8) and Conplant Ferti (Campinas, Brazil) for the fertilizer donation.

${ }^{1}$ These authors contributed equally to this work as the joint first authors.

${ }^{2}$ To whom reprint requests should be addressed; e-mail rhuanito@terra.com.br. resin and laminating fiberglass blanket (both from Redelease, São Paulo, Brazil), and a container support structure, made with 37-mm diameter PVC tubes (Tigre, Joinville, Brazil) (Fig. 1A and B). These tubes reduced the amount of nutrient solution used and maintained the spacing required in citrus production system for proper rootstock development. Uva et al. (2001) described this subirrigation equipment as a Dutch tray. The prototype dimensions $(62 \times 41 \times 12 \mathrm{~cm}$, length $\times$ width $\times$ height) (Fig. 1C and D) were based on the commercial flat trays used by growers to support the containers and in the stands available in production units, ensuring that the use of this new equipment would not require changes at the current production system. The commercial flat trays used as a reference have dimensions of $69.5 \times 42 \times 3 \mathrm{~cm}$ and 228 -cell capacity $(19 \times 12)$. Our tray had 54 cells (nine $\times$ six), receiving up to 54 containers simultaneously and presenting a greater spacing among cells to favor plant growth. The bottom of the tray was beveled to facilitate drainage, which occurred through a $1.5-\mathrm{cm}$ hole (Fig. 1E).

Treatments. Plants were irrigated at different water levels, allowing the substrate wetting by capillary action. We tested three treatments: T1) subirrigation with water reaching two-thirds of the container height (up to $8 \mathrm{~cm}$ of water from its base); T2) subirrigation with water reaching one-third of the container height (up to $4 \mathrm{~cm}$ of water from its base); and T3) a control with manual overhead irrigation using a hose with a shower head. The T1 and T2 water levels were chosen based on a previous study using the same substrate (Barreto et al., 2012). The T3 treatment was the standard irrigation technique used in $92 \%$ of citrus seedlings nurseries according to Almeida (2003) and Salvador (2010).

Plants were irrigated daily at $0800 \mathrm{HR}$ for $15 \mathrm{~min}$ in all treatments. Fertigation was performed every $3 \mathrm{~d}$ until 60 DAS and every $2 \mathrm{~d}$ after 60 DAS using a nutrient solution with an electrical conductivity of $1.9 \mathrm{dS} \cdot \mathrm{m}^{-1}$ and $\mathrm{pH}$ 4.24. This solution was prepared using $3 \mathrm{~mL} \cdot \mathrm{L}^{-1}$ of FloriSol Veg (Conplant Ferti, Campinas, Brazil) plus $0.3 \mathrm{~g} \cdot \mathrm{L}^{-1}$ of magnesium sulfate (Produquímica, Suzano, Brazil) with final concentrations $\left(\mathrm{mg} \cdot \mathrm{L}^{-1}\right)$ of elements as follows: total-nitrogen $(\mathrm{N})=198$ $\left(\mathrm{NH}_{4}-\mathrm{N}=24\right.$ and $\left.\mathrm{NO}_{3}-\mathrm{N}=174\right)$, phosphorus $=$ 31 , potassium $=187$, calcium $=143$,
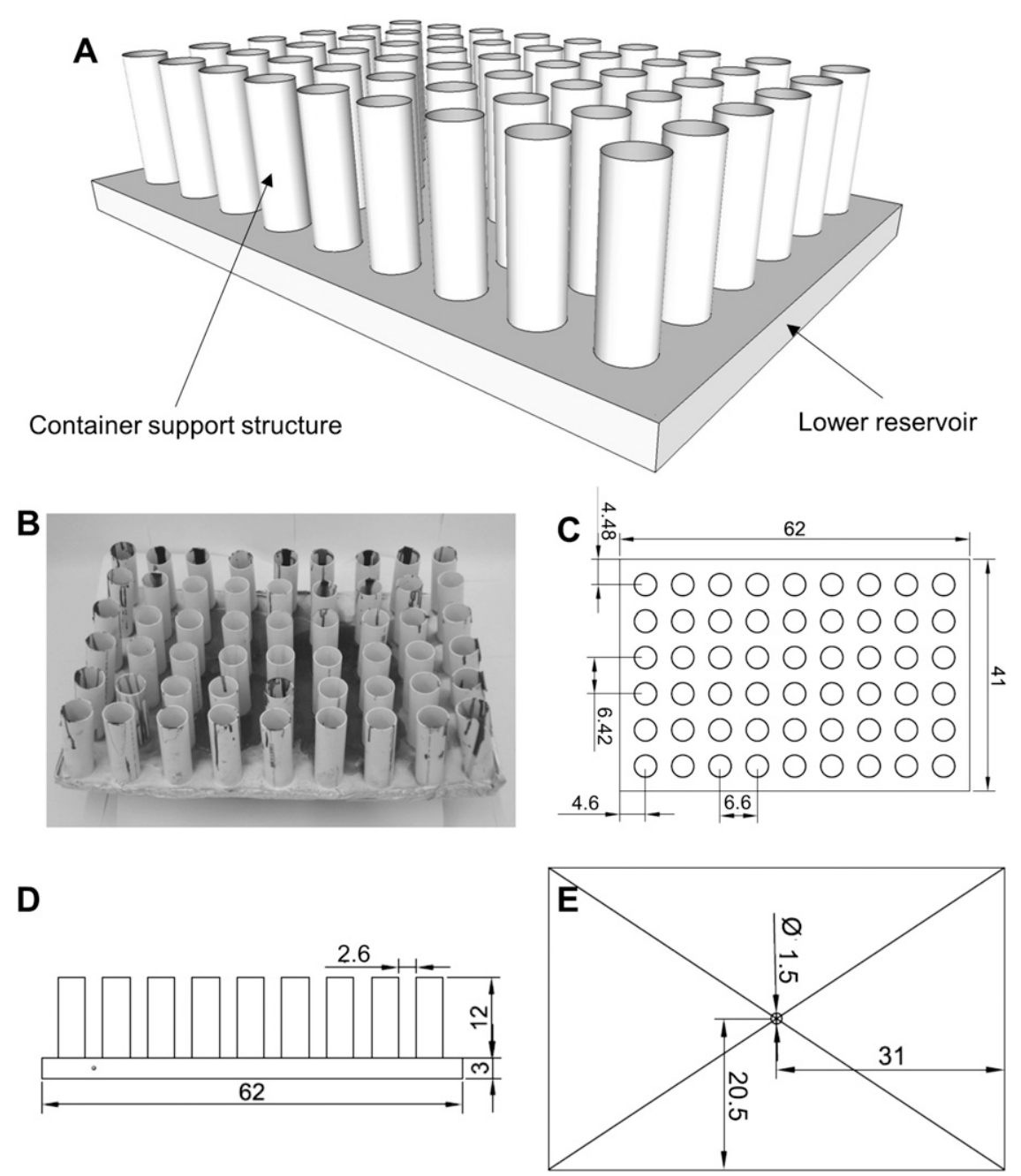

Fig. 1. Subirrigation prototype tray composed by a lower reservoir made of acrylic resin and fiberglass and a container support structure made with $37-\mathrm{mm}$ diameter polyvinyl chloride tubes. (A) Threedimensional view, (B) photography, (C) top view, (D) side view, and (E) bottom view. Dimensions in centimeters. Figure A by Antonio Carlos Ferreira Filho. 
magnesium $=60$, sulfur $=36$, boron $=0.5$, copper $=0.5$, iron $=1.8$, manganese $=0.5$, molybdenum $=0.1$, nickel $=0.1$, and zinc $=0.2$.

Measurements. We determined the plant growth parameters of dry mass (leaves, stem, and root), leaf area, root length, shoot height, and stem diameter at $3 \mathrm{~cm}$ from the base at 36 , 55, 75, and 90 DAS. We sampled three plants per plot, replacing the empty spots with other plants to maintain spacing and light between plants (these plants were labeled and not used for further sampling). Plant tissues were dried in a forced-air oven for $48 \mathrm{~h}$ at $65^{\circ} \mathrm{C}$. Because lime is a plant with hypogeal germination, the cotyledon insertion was considered as the division between the stem and roots. Leaf area was measured using an LI-3100 leaf area meter (LI-COR, Lincoln, NE).

We evaluated plant morphology at 55, 75, and 90 DAS by counting the number of bifurcations. We also measured the physiological parameters of carbon assimilation rate at $36,55,75$, and $90 \mathrm{DAS}$; leaf water potential at 36, 55, 67, 75, and $90 \mathrm{DAS}$; and leaf temperature, transpiration, and stomatal resistance at 36, 55, and 90 DAS. We sampled three plants per plot for each sampling date. The gaseous exchange measurements from the porometer LI-1600 (LI-COR) were used to determine the average carbon assimilation rate defined by Ranney et al. (1991) (Eq. [1]):

$$
\ddot{E}=\frac{2(D M 2-D M 1)}{(L a 2-L a 1)(T 2-T 1)}
$$

where: La2 and La1 = leaf area in final and initial times $\left(\mathrm{cm}^{2}\right)$, respectively; DM1 and DM2 = dry mass in the initial and final times (g), respectively; and $\mathrm{T} 2$ and $\mathrm{T} 1=$ final and initial time (day), respectively.

To assess the leaf water potential, we sampled the third fully expanded leaf for each data collection day using a pressure bomb Model 1002 (PMS Instrument Co., Albany, OR) and the LI-1600 porometer. On DAS 55, the evaluations were performed at $0800,1000,1200$ and $1400 \mathrm{HR}$ with the porometer, and at predawn, 0800, 1000, 1200, and $1400 \mathrm{HR}$ with the pressure bomb. At 36 and 75 DAS, we measured predawn and midday leaf water potential, and measured gaseous exchange at midday. At 55 and 90 DAS, only leaf water potential readings were taken at predawn and midday.

Experimental design and statistical analysis. The study was arranged in a randomized block design with five replications, totaling 15 trays with 54 plants in each plot. Data were analyzed using mean comparison test (Tukey honestly significant difference test) in SAS 9.2 (SAS Institute Inc., Cary, NC) and regression analyses in Sigma Plot 11 (Jandel Scientific, Corte Madera, CA). The results were considered significant when $P<0.05$.

\section{Results and Discussion}

Plant growth. The subirrigated seedlings presented greater plant growth, most likely because of higher water availability. The differences in growth also may be related to nutritional differences among irrigation treatments, because subirrigation would push more nutrients into the root zone than the overhead irrigation. Subirrigated treatments promoted the highest leaves, stems, and total dry mass at 75 and 90 DAS compared with
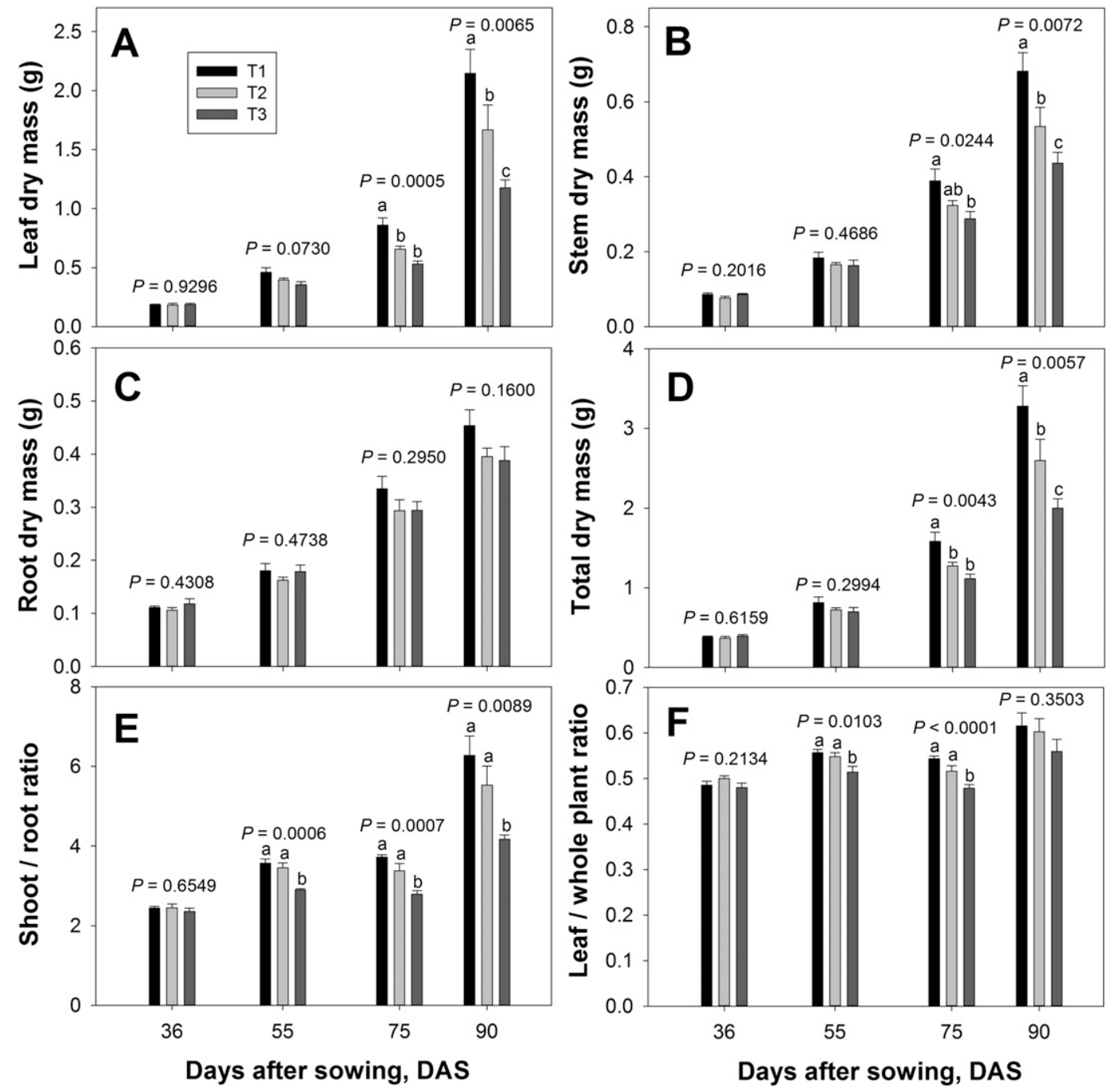

Fig. 2. Leaf (A), stem (B), root (C), and total (D) dry mass, shoot/root ratio (E), and leaf/whole plant ratio (F) of Rangpur lime at 36, 55, 75, and $90 \mathrm{~d}$ after sowing (DAS). Plants were grown under three treatments: T1) subirrigation with water reaching two-thirds of the container height $(8 \mathrm{~cm})$; T2) subirrigation with water reaching one-third of the container height $(4 \mathrm{~cm})$; and T3) control with manual overhead irrigation. Means followed by different letters differ significantly according to a Tukey mean comparison test at $5 \%$ probability $(P<0.05)$. The values are the average (mean $\pm \mathrm{SE})$ of three plants per treatment and five replications. 
manually irrigated plants (T3; Fig. 2A, B, and $\mathrm{D}, P<0.001)$. The leaf dry mass under T1 was $83 \%$ higher than in T3 at the end of the study (Fig. 2A, $P=0.0065$ ). We observed an increase in shoot dry mass in subirrigated treatments, which, however, was not followed by an increase in root dry mass (Fig. 2C, $P>$ 0.05 ). There was vigorous vegetative growth throughout the study with significant treatment effects over time and a higher total dry mass accumulation in T1 plants at 90 DAS (Fig. 2D, $P=0.0057$ ). Total dry mass in T1 was $64 \%$ higher than T3 and 26\% higher than T2.

The change in the shoot/root ratio observed at 55, 75, and 90 DAS (Fig. 2E, $P<$ 0.001 ) was beneficial because the growth was continuous with abundant foliage, allowing the seedlings transplanting for the further phases on time and with the desired size. Our results were similar to Baldassari et al. (2003), who indicated that high shoot/root ratio values are essential for avoiding citrus decline disease. Unlike the findings of Espeleta and Eissenstat (1998) and Hartmond et al. (1987), our study showed an adequate shoot/ root ratio as a result of the positive effect of substrate moisture on plant growth. These authors examined continuous subirrigation using sweet orange (Citrus sinensis L. Osbeck 'Pineapple'), citrange (Citrus sinensis L. Osbeck $\times$ Poncirus trifoliata 'Carrizo'), sour orange (Citrus aurantium L.), and Volkamer lemon (Citrus volkameriana Tan. \& Pasq.) rootstocks and found lack of response as a result of stress caused by reduced oxygenation of the roots.

The leaf/whole plant ratio was higher for the subirrigated treatments, except at 36 and 90 DAS (Fig. 2F, $P<0.001$ ). This is also in agreement with the results obtained by Espeleta and Eissenstat (1998) and Hartmond et al. (1987).

Similar to dry mass, T1 plants displayed shoot height higher than the other treatments; however, there was no significant difference in the first half of the crop cycle. Plants under T1 reached $15 \mathrm{~cm}$ at 52 DAS, $18 \mathrm{~cm}$ at 60 DAS, and $20 \mathrm{~cm}$ at 66 DAS (Fig. 3A). Plants under T3 achieved similar shoot heights later at 64, 79, and 90 DAS (Fig. 3A). In the intermediate condition, T2 plants displayed such values at 55, 66, and 73 DAS. Comparing the $\mathrm{T} 1$ plant cycle with the T3, we noted that plants under T1 grew at a faster rate, obtaining a shoot height of $15 \mathrm{~cm} 12 \mathrm{~d}$ earlier, $18 \mathrm{~cm} 19 \mathrm{~d}$ earlier, and $20 \mathrm{~cm} 24 \mathrm{~d}$ earlier (Fig. 3A, $P<$ 0.001). Comparing T2 with $\mathrm{T} 3$, there was a difference of 9,13 , and $17 \mathrm{~d}$ in cycle shortening. There was no treatment differences for stem diameter (Fig. 3B, $P>0.05$ ).

The largest shoot height and stem diameter found in subirrigated plants were similar to those found by Landis (2005) studying two native plants [blue spruce (Picea pungens) and pale purple coneflower (Echinacea pallida)] using subirrigation as well. The greater plant growth in our study shortened the crop cycle, especially when comparing the highest water level (T1) with the manual overhead irrigation (T3). This precocity is important in citrus because the transplanting into 5-L bags is usually performed when plants reach a shoot height of $18 \mathrm{~cm}$ for grafting (Boaventura et al., 2004). According to Almeida (2003), seedlings are commonly kept in conic containers until a shoot height of 15 to $18 \mathrm{~cm}$, attained
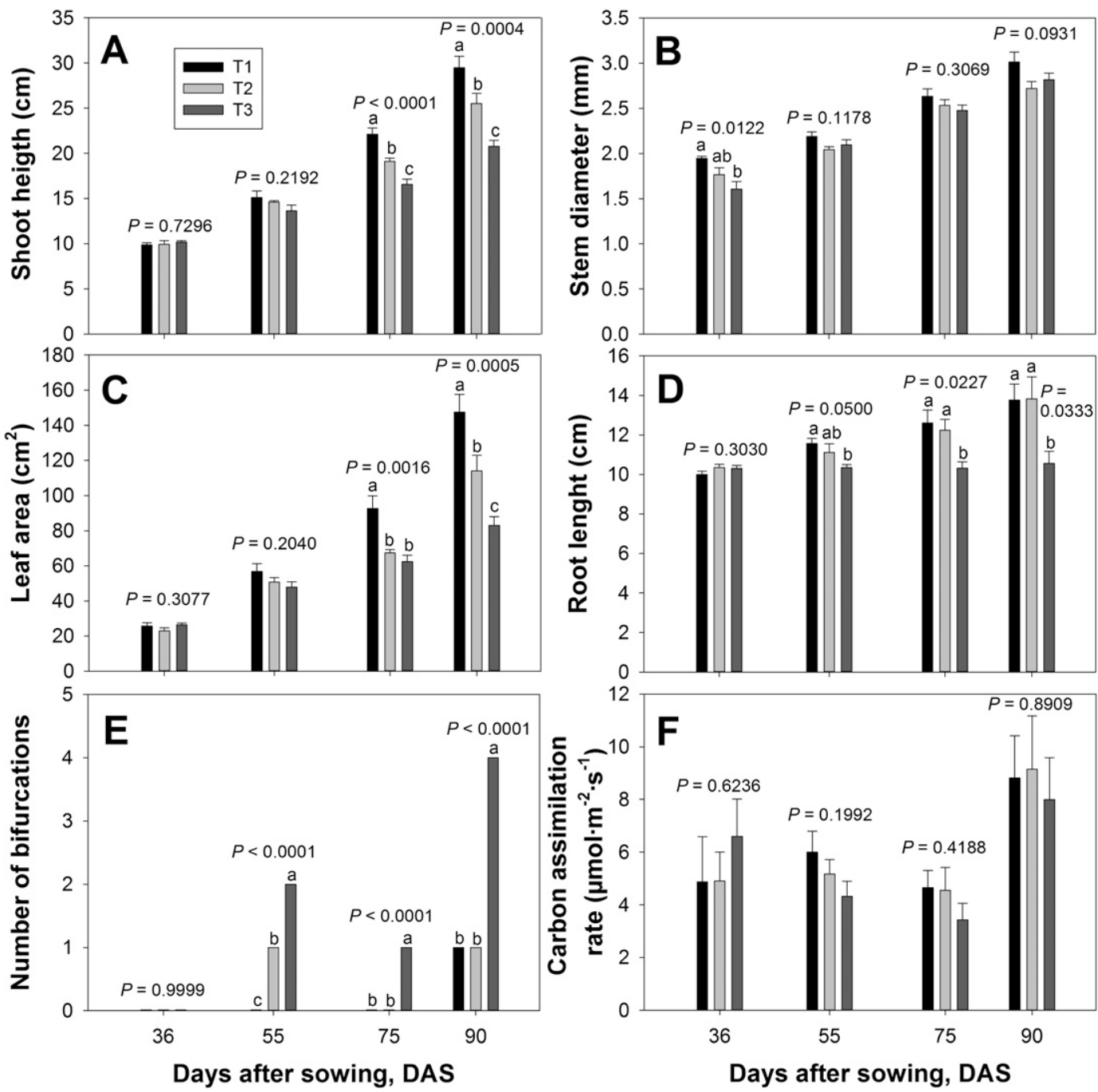

Fig. 3. Shoot height (A), stem diameter (B), leaf area (C), root length $(\mathbf{D})$, number of bifurcations $(\mathbf{E})$, and carbon assimilation rate (F) of Rangpur lime at 36, 55, 75 , and $90 \mathrm{~d}$ after sowing (DAS). Plants were grown under three treatments: T1) subirrigation with water reaching two-thirds of the container height (8 $\mathrm{cm}$ ); T2) subirrigation with water reaching one-third of the container height $(4 \mathrm{~cm})$; and T3) control with manual overhead irrigation. Means followed by different letters differ significantly according to a Tukey mean comparison test at $5 \%$ probability $(P<0.05)$. The values are the average (mean \pm SE) of three plants per treatment and five replications. 
when plants are $\approx 3$ to 4 months old. Plants grown under T1 reached a shoot height of $15 \mathrm{~cm}$ at 52 DAS (less than 2 months) and $29.4 \mathrm{~cm}$ at 90 DAS, which was two times taller than the $15-\mathrm{cm}$ value recommended for transplanting by Almeida (2003).

The results indicated better plant growth with water level of two-thirds of the container height (T1) for 75 and 90 DAS (Fig. 3A and C, $P<0.001)$. The rootstocks under this treatment had higher shoot height, leaf area, and root length (Fig. 3, $P<0.05$ ). The control (T3) was probably subject to lower volumetric water contents compared with the other treatments. The higher hydraulic conductivity of the root system of Rangpur limes under drought (Medina et al., 1998) results in higher water consumption and hence increased need for irrigation (Machado et al., 1999; Soares, 2003). For these factors, Rangpur lime plants grown in T1 responded with more growth. Plants from T3 presented the lowest shoot development, leaf area, and root length (Fig. 3, $P<0.05$ ), probably as result of lower water and nutrient availability. Subirrigation concentrates ions at the substrate (Richards and Reed, 2004), whereas manual overhead irrigation usually leaches out the nutrients. There was no reduction in $\mathrm{T} 1$ or $\mathrm{T} 2$ seedlings root length (Fig. 3D, $P<0.05$ ) as a result of plant stress caused by oversaturation as reported by Ranney et al. (1991), who used subirrigation in cherry tree seedling production. In contrast, we noticed that subirrigated roots left the containers because of the water availability in the bottom reservoir (data not shown).

However, it is important to note that the effect of subirrigation on citrus rootstock seedlings is variety- and container-dependent. According to Teixeira et al. (2009), larger growing cells provided higher shoot and root growth and shoot/root ratio. These authors tested trifoliate orange [Poncirus trifoliata (L.) Raf.], citrange 'FEPAGRO C37' [Poncirus trifoliata (L.) Raf. $\times$ Citrus sinensis (L.) Osbeck.], and tangerine 'Sunki' (Citrus sunki hort. ex Tan.) and two container types (conic containers and isoprene trays) using subirrigation.

Plant morphology. We observed stem bifurcations since the second sampling date, which were more pronounced for T3 (Fig. 3E, $P<0.0001)$. High number of bifurcations is an undesired effect, because of the increase in labor costs for pruning. Two stem bifurcations were counted in T3 and one in T2 at 55 DAS, one in $\mathrm{T} 3$ at $75 \mathrm{DAS}$, and one in $\mathrm{T} 1$ and $\mathrm{T} 2$ and four for T3 at 90 DAS. Throughout the experiment, there were seven bifurcated plants in the T3 group, whereas two were counted for T2 and just one for T1. The breaking of apical dominance was higher for T3 (Fig. 3E, $P<0.0001$ ). Plants under this treatment displayed less growth, and this may be related to the irrigation system that provided less available water. The principles involved in the resumption of shoot buds are not well known and are often contradictory, mainly because it involves many factors such as photoperiod, temperature, and soil moisture availability (Medina et al., 2005).

Plant physiology. There was no treatment effect on predawn and midday carbon

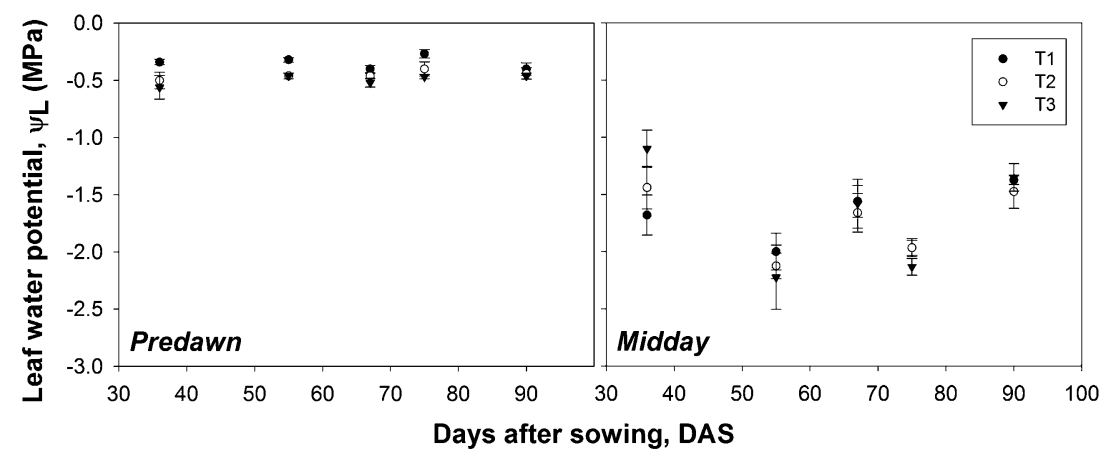

Fig. 4. Leaf water potential of Rangpur lime seedlings at predawn and midday throughout the study. Plants were grown under three treatments: T1) subirrigation with water reaching two-thirds of the container height ( $8 \mathrm{~cm}) ; \mathrm{T} 2)$ subirrigation with water reaching one-third of the container height $(4 \mathrm{~cm})$; and T3) control with manual overhead irrigation. Absence of regression lines indicate no significance at 5\% probability $(P>0.05)$. The values are the average (mean $\pm \mathrm{sE})$ of three plants per treatment and five replications.

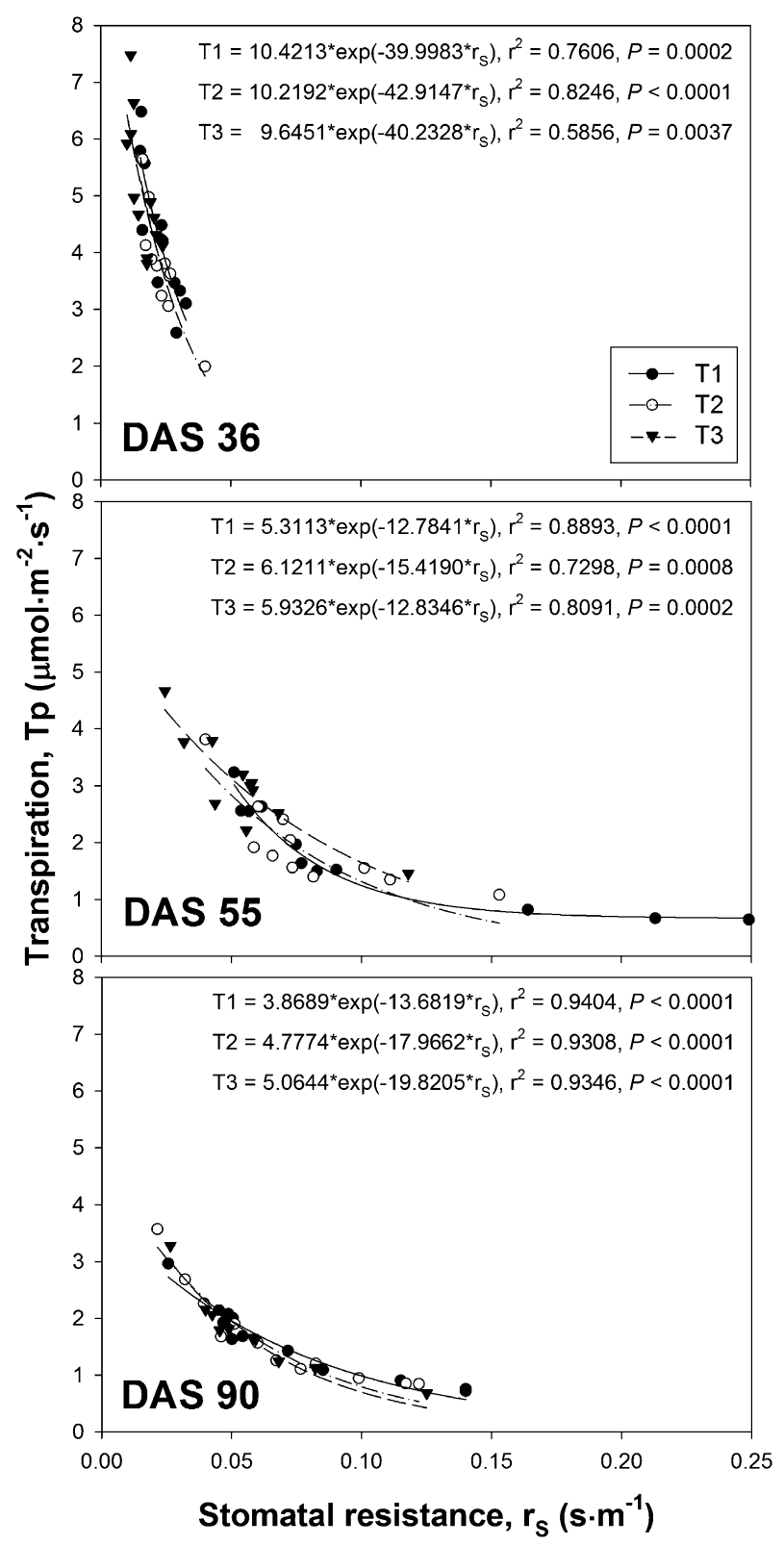

Fig. 5. Correlation between transpiration and stomatal resistance at midday at 36,55 , and $90 \mathrm{~d}$ after sowing (DAS). Plants were grown under three treatments: T1) subirrigation with water reaching two-thirds of the container height $(8 \mathrm{~cm})$; T2) subirrigation with water reaching one-third of the container height $(4 \mathrm{~cm})$; and T3) control with manual overhead irrigation. 

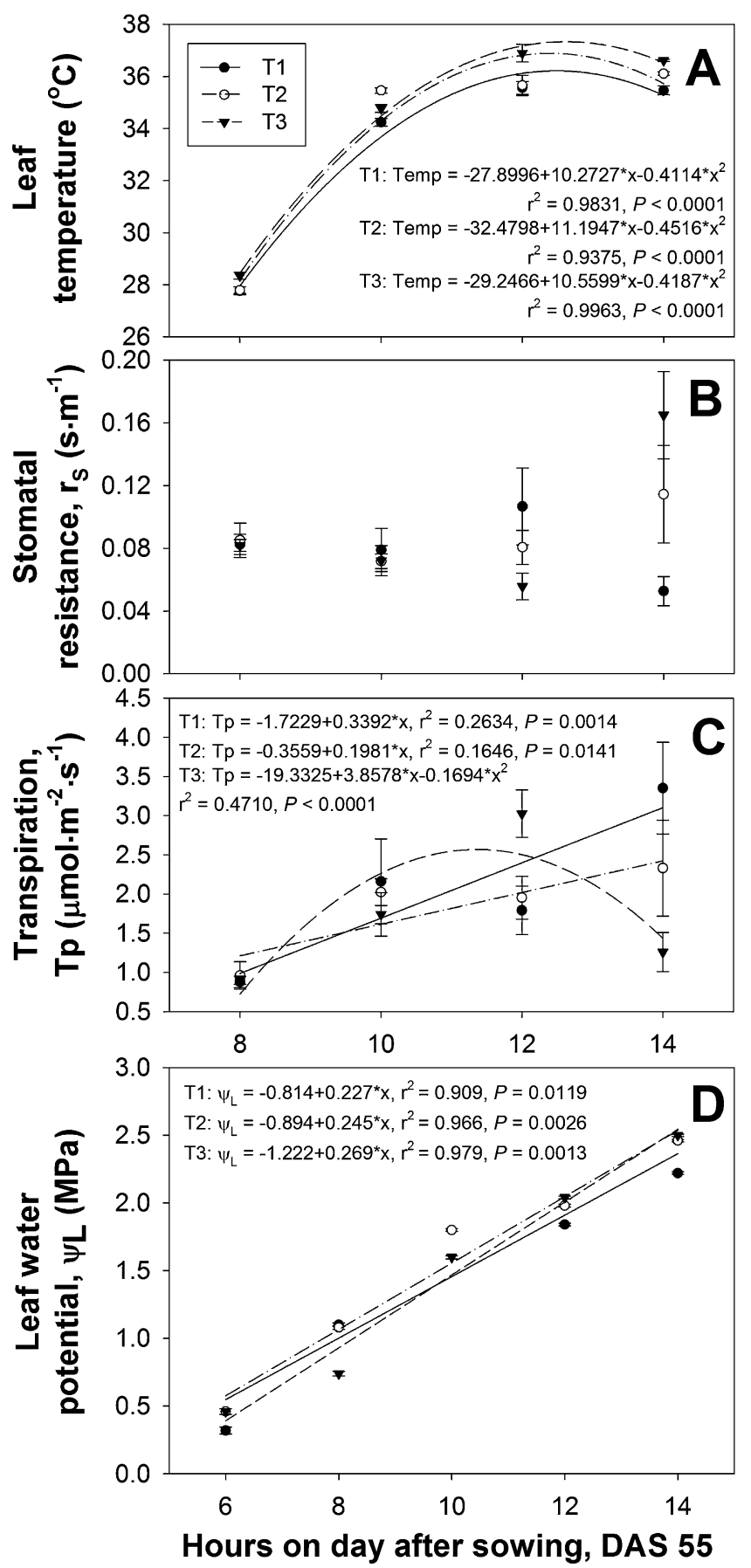

Fig. 6. Leaf temperature (A), stomatal resistance (B), transpiration (C), and leaf water potential (D) of Rangpur lime rootstocks determined every $2 \mathrm{~h}$ at $55 \mathrm{~d}$ after sowing (DAS). Plants were grown under three treatments: T1) subirrigation with water reaching two-thirds of the container height $(8 \mathrm{~cm}) ; \mathrm{T} 2)$ subirrigation with water reaching one-third of the container height $(4 \mathrm{~cm})$; and T3) control with manual overhead irrigation. Absence of regression lines indicate no significance at $5 \%$ probability $(P>0.05)$. The values are the average (mean $\pm \mathrm{SE})$ of three plants per treatment and five replications.

assimilation rate (Fig. 3F, $P>0.05)$ and leaf water potential during the crop cycle (Fig. 4A and $\mathrm{B}, P>0.05$ ), although our treatments showed differences in plant growth. The absence of significance on these physiological parameters was probably the result of our sampling method. Leaf photosynthesis measurements are often poorly correlated with dry matter production and yield (Elmore, 1980). According to van Iersel and Bugbee (2000), reasons for this poor correlation are attributable to the fact that the entire leaf or even the canopy may not be representative of the section of the leaf that is measured, diurnal and during development changes in leaf $\mathrm{CO}_{2}$ exchange, and respiratory $\mathrm{CO}_{2}$ efflux of roots and shoots is not measured. Whole canopy measurements bypass the problem of finding a representative leaf and have been used successfully (Wells, 1991). Zelitch (1982) showed a good correlation between canopy photosynthesis throughout the growing season and yield. This correlation would be expected to improve as measurements are taken more often. Moreover, subirrigation causes an increase in volumetric water content right after water application (Ferrarezi et al., 2014), resulting in higher values of soil moisture kept for a longer period, not imposing water stress to plants that can be detected by the porometer (Geneve et al., 2004). Hence, plant growth parameters were the best indicators of treatment effects.

By correlating the values of transpiration and stomatal resistance, we obtained a stomatal adjustment curve. T1 and T2 plants tended to reduce the midday stomatal resistance and increase transpiration at 36 DAS (Fig. 5, $P<$ $0.001)$, which indicates absence of stress according to Medina et al. (2005). T2 and T3 plants displayed higher water loss by transpiration (0.02 and $\left.0.025 \mathrm{~s} \cdot \mathrm{m}^{-1}\right)$ compared with T1, especially T3 (Fig. 5, $P=0.0037$ ). The data at 55 DAS also indicated less water loss by transpiration for T1 (Fig. $5, P<0.001$ ). Conversely, T3 displayed higher transpiration at all levels of stomatal resistance (Fig. 5, $P=0.0002$ ). Medina et al. (1999) indicated an increase in stomatal resistance at high temperatures such as those that occur at midday. Under this condition, improved efficiency in stomatal closure of $\mathrm{T} 1$ and $\mathrm{T} 2$ plants were noted in comparison with T3 plants (Fig. 5, $P<0.001)$. This phenomenon is consistent with Sojka (1992), who indicated changes in the diffusivity of gases and morphology of several species during prolonged periods of saturation. However, the stomatal regulation for water loss such as found in T3 was contrary to Medina et al. (2005). According to these authors, the amount of water transpired by the plant is directly proportional to the water available for its development. Greater water availability from T1 favored stomatal aperture and transpiration, a process essential to the carbon assimilation, which facilitated the achievement of higher growth of subirrigated citrus rootstocks seedlings. This was also observed by Teixeira et al. (2009) using subirrigation in trifoliate orange, citrange 'FEPAGRO C37', and tangerine 'Sunki'.

The increase in stomatal openings in citrus is positively linked to the increase in the turgor pressure of the guard cells and negatively correlated to adjacent cells and subsidiaries in the epidermis surrounding the guard cells (Steppe et al., 2006). The turgidity of guard cells and other tissues surrounding the stomata can play an important role in the stomatal regulation (Medina et al., 2005). The closing of the stomatal pores leads to increased stomatal resistance, which would prevent virtually all $\mathrm{CO}_{2}$ intake (Medina et al., 2005). However, when the water content in citrus leaves drops below a certain threshold value, the stomata closes with consequent reduction of transpiration and carbon assimilation (Medina et al., 2005). Thus, it is understandable that the T3 plants would present a slightly lower turgor pressure because of the lower amount of water in the plant, not favoring stomatal regulation (Fig. 5, $P<0.001$ ). 
We observed an increase of leaf temperature (Fig. 6A, $P<0.0001$ ), transpiration (Fig. 6C, $P<0.05$ ), and leaf water potential (Fig. $6 \mathrm{D}, P<0.05$ ) over time in the evaluation performed at 55 DAS. The T2 and T3 treatments displayed leaf temperature higher than the air temperature in the hottest hours of the day, a condition in which the leaf loses water and closes stomata (Medina et al., 2005). The lower stomatal resistance measured at $1000 \mathrm{HR}$ for all treatments (Fig. 6B, $P>0.05$ ) was similar to the results of Medina et al. (1999), who found greater stomatal conductance in plants grafted on Rangpur lime when performing the measurements at $0900 \mathrm{HR}$. The greater transpiration or loss of water per unit area of open stomata started at $\approx 1100 \mathrm{HR}$ with an increase in transpiration until $1400 \mathrm{HR}$ for T1 and T2 (Fig. 6C, $P<$ $0.05)$. T3 plants displayed higher transpiration over daytime, except at $1400 \mathrm{HR}$ (Fig. 6C, $P=0.0014)$. Regarding leaf water potential (Fig. 6D, $P<0.001$ ), the lowest value was found under T3 at $0600 \mathrm{HR}$ with subsequent reversal between 1000 and 1200 HR to more negative leaf water potentials. The physiological responses of $\mathrm{T} 1$ indicated a direct relation between higher substrate water content and better plant development (Fachini et al., 2004). Hydrated plants usually have higher transpiration (Medina et al., 1999), and this process is associated with more carbon assimilation as a result of stomatal opening (Medina et al., 2005).

\section{Conclusions}

The subirrigation prototype tray has been proven to be suitable for the production of Rangpur lime rootstocks and capable of increasing plant growth. Subirrigated plants displayed higher total dry mass, shoot/root and leaf/whole plant ratios, shoot height, leaf area, and root length, resulting in a shortened crop cycle. Plants irrigated manually presented a higher number of bifurcations, needing labor use for pruning. Plants under T1 displayed better resilience to daily water stress because of stomatal efficiency. The lower efficiency in stomatal closure of plants under T3, which is attributed to the smaller amount of water available to support guard cell turgor, resulted in reduced carbon buildup. The treatment that supplied a water level of two-thirds of the container height $(8 \mathrm{~cm})$ produced the biggest Rangpur lime seedlings. The anticipation in plant cycle resulting from higher plant growth is beneficial for early transplanting for grafting, potentially increasing the nursery annualized productivity.

\section{Literature Cited}

Almeida, E.L.P. 2003. Production systems of citrus seedling in protected nursery trees in São Paulo State. MS thesis, São Paulo State Univ., Botucatu, Brazil.

Augusto, D.C.C., I.A. Guerrini, V.L. Engel, and G.X. Rousseau. 2007. Use of biologically treated wastewater in Eucalyptus grandis Hill. ex. Maiden seedling production by continuous subirrigation. Revista Árvore 31:745-751.
Baldassari, R.B., A.D. Goes, and F. Tannuri. 2003. Citrus blight: Is there something about the nursery trees production? Revista Brasileira de Fruticultura 25:357-360.

Bañuls, J. and E. Primo-Millo. 1995. Effects of salinity on some citrus scion-rootstock combinations. Ann. Bot. (Lond.) 76:97-102.

Barreto, C.V.G., R. Testezlaf, and C.A. Salvador. 2012. Dynamics of matric potential on substrates of pine and coconut under the action of capillarity. Horticultura Brasileira 30:26-31.

Boaventura, P.R.R., J.A. Quaggio, M.F. Abreu, and O.C. Bataglia. 2004. Nutrient balance for citrus nurseries production in substrate under screenhouse. Revista Brasileira de Fruticultura 26:300305.

Brazilian Ministry of Development Industry and Foreign Trade. 2012. Exports of Brazilian agricultural sector. Department of Foreign Trade, Brasília. 24 Mar. 2013. <http://www.desenvolvimento.gov.br/ sitio/interna/index.php?area $=5>$.

Brazilian Ministry of Planning Budget and Management. 2012. Systematic survey of agricultural production. Brazilian Institute of Geography and Statistics, Brasília. 13 June 2013. <http:// www.ibge.com.br>

Carvalho, S.A., C.C.D. Graf, and A.R. Violante. 2005. Produção de material básico e propagação, p. 281-311. In: Mattos Júnior, D., J.D. De Negri, R.M. Pio, and J. Pompeu Júnior (eds.). Citros. Instituto Agronômico, Campinas, Brazil.

Elmore, C.D. 1980. The paradox of no correlation between leaf photosynthetic rates and crop yields, p. 155-167. In: Hesketh, J.D. and J.W. Jones (eds.). Predicting photosynthesis for ecosystem models. Vol. 2. CRC Press, Boca Raton, FL.

Espeleta, J.F. and D.M. Eissenstat. 1998. Responses of citrus fine roots to localized soil drying: A comparison of seedlings with adult fruiting trees. Tree Physiol. 18:113-119.

Fachini, E., J.A. Galbiatti, and L.C. Pavani. 2004. Levels of irrigation and types of substrate utilizing organic waste compost in the production of orange. Engenharia Agrícola 24:578-588.

Ferrarezi, R.S., M.W. van Iersel, and R. Testezlaf. 2014. Subirrigation automated by capacitance sensors for salvia production. Horticultura Brasileira 32:314-320.

García-Sánchez, F., J.P. Syvertsen, V. Gimeno, P. Botía, and J.G. Perez-Perez. 2007. Responses to flooding and drought stress by two citrus rootstock seedlings with different wateruse efficiency. Physiol. Plant. 130:532-542.

Geneve, R.L., S.T. Kester, and J.W. Buxton. 2004 Capillary mats alter the water content in medium during mist propagation of Dendranthema. HortScience 39:584-587.

Gonçalves, F.P., E.S. Stuchi, S.R. Silva, E.T. Reiff, and L. Amorim. 2011. Role of healthy nursery plants in orange yield during eight years of Citrus Variegated Chlorosis epidemics. Sci. Hort. 129:343-345.

Hartmond, U., N.V. Schaesberg, J.H. Graham, and J.P. Syvertsen. 1987. Salinity and flooding stress effects on mycorrhizal and non-mycorrhizal citrus rootstock seedlings. Plant Soil 104:3743.

Landis, T.D. 2005. Water potential. USDA Forest Service, Washington, DC. Forest Nursery Notes Summer:1-39.

Landis, T.D., K. Dumroese, and R. Chandler. 2006. Subirrigation trials with native plants. USDA Forest Service, Washington, DC. Forest Nursery Notes Winter: $1-38$.

Machado, E.C., C.L. Medina, and M.M.A. Gomes. 1999. Substrate water content and photosyn- thesis in 'Valencia' orange trees. Bragantia 58:217-226.

Machado, E.C., P.T. Schmidt, C.L. Medina, and R.V. Ribeiro. 2005. Photosynthetic responses of three citrus species to environmental factors. Pesquisa Agropecu. Bras. 40:1161-1170.

Medina, C.L., E.C. Machado, and M.M.A. Gomes. 1999. Stomatal conductance, transpiration and photosynthesis rates in 'Valencia Orange' trees subjected to water stress. Rev. Bras. Fisiol. Vegetal 11:29-34.

Medina, C.L., E.C. Machado, and M.J. Pinto. 1998. Photosynthesis of 'Valência' tree grafted on four rootstocks and subjected to water deficit. Bragantia 57:1-14.

Medina, C.L., A.B. Rena, D.L. Siqueira, and E.C. Machado. 2005. Fisiologia dos citros, p. 147195. In: Mattos Júnior, D., J.D. De Negri, R.M. Pio, and J. Pompeu Júnior (eds.). Citros. Instituto Agronômico, Campinas, Brazil.

Million, J.B., J.E. Barrett, T.A. Nell, and D.G. Clark. 1999. Inhibiting growth of flowering crops with ancymidol and paclobutrazol in subirrigation water. HortScience 34:11031105.

Pimentel, C., C. Bernacchi, and S. Long. 2007. Limitations to photosynthesis at different temperatures in the leaves of Citrus limon. Braz. J. Plant Physiol. 19:141-147.

Ranney, T.G., N.L. Bassuk, and T.H. Whitlow. 1991. Influence of rootstock, scion, and water deficits on growth of 'Colt' and 'Meteor' cherry trees. HortScience 26:1204-1207.

Richards, D.L. and D.W. Reed. 2004. 'New Guinea' impatiens growth response and nutrient release from controlled-release fertilizer in a recirculating subirrigation and top-watering system. HortScience 39:280-286.

Salvador, C.A. 2010. Irrigation system by capillary action in the citrus rootstocks production in seedling stage. MS thesis, Univ. of Campinas, Campinas, Brazil

Soares, T.M. 2003. Citrus rootstocks growth using salty water. MS thesis, Univ. of São Paulo, Piracicaba, Brazil.

Sojka, R.E. 1992. Stomatal closure in oxygenstressed plants. Soil Sci. 4:269-280.

Steppe, K., S. Dzikiti, R. Lemeur, and J.R. Milford. 2006. Stomatal oscillations in orange trees under natural climatic conditions. Ann. Bot. (Lond.) 97:831-835.

Teixeira, P.T.L., G. Schäfer, P.V.D. Souza, and A. Todeschini. 2009. Vegetative development of citric rootstocks produced in different containers. Ciência Rural 39:1695-1700.

Uva, W.L., T.C. Weiler, and R.A. Milligan. 2001. Economic analysis of adopting zero runoff subirrigation systems in greenhouse operations in the northeast and north central United States. HortScience 36:167-173.

van Iersel, M.W. and B. Bugbee. 2000. A multiple chamber, semicontinuous, crop carbon dioxide exchange system: Design, calibration, and data interpretation. J. Amer. Soc. Hort. Sci. 125:86-92.

Verdial, M.F., A.Y. Iwata, M.S. Lima, and J. Tessarioli Neto. 1998. Influence of floating on the growth of sweet pepper (Capsicum annuum L.) seedlings. Scientia Agricola 55:25-28.

Wells, R. 1991. Soybean growth response to plant density: Relationships among canopy photosynthesis, leaf area, and light interception. Crop Sci. 31:755-761.

Zelitch, I. 1982. The close relationship between net photosynthesis and crop yield. Bioscience 32:796-802. 